\title{
Role of hydrogen sulfide in the regulation of respiration, blood flow and bile secretory function of the liver
}

\author{
P.I. Yanchuk, I.V. Komarov, Y.A. Levadianska, L.O. Slobodianyk, \\ S.P. Veselsky, T.V. Vovkun, L.Ya. Shtanova, E.M. Reshetnik \\ Taras Shevchenko National University of Kyiv,Ukraine; e-mail: yanchuk49@ukr.net
}

\begin{abstract}
In acute experiments on laboratory rats, intra-portal administration of L-cysteine $(20 \mathrm{mg} / \mathrm{kg})$, the precursor of hydrogen sulfide synthesis, stimulated oxygen consumption of liver by $38.6 \%$ and reduced oxygen tension by $37.1 \%$. Activation of tissue respiration occurred due to the strengthening of oxygen-dependent synthetic processes in liver, in particular those associated with mitochondrial enzyme-catalysed bile acid biosynthesis through the acidic pathway. The concentrations of taurocholic acid and mixtures of taurodeoxycholic and taurohenodeoxycholic acids increased by 10.3 and $17.9 \%$, respectively, compared to the initial levels. In addition, the level of free cholesterol was decreased by $33.9 \%$ and esterification processes were intensified, as indicated by an increase in the concentration of esterified cholesterol by $22.6 \%$ in the bile of rats. The latter was to some extent confirmed by a decrease in the level of free bile acids (by 15.8\%) involved in the biosynthesis of cholesterol esters and intensification of tissue respiration in the liver. L-cysteine dilated intrahepatic vessels, resulting in a significant decrease of the systemic blood pressure and blood pressure in the portal vein by 17.6 and $24.5 \%$, respectively. L-cysteine increased the rate of local blood flow in the liver and blood supply by 28.2 and $24.4 \%$, respectively. Blockade of cystathionine- $\gamma$-lyase by DL-propargylglycine (11 mg/kg) significantly inhibited the L-cysteine-induced tissue respiration and bile acid biosynthesis in the liver. Administration of DL-propargylglycine resulted in constriction of blood vessels of the liver and, as a consequence, to an increased blood pressure and a decreased blood flow rate in tissue. Our data point to an involvement of hydrogen sulfide in the regulation of liver tissue respiration and bile secretory function. Key words: hydrogen sulfide; L-cysteine; liver; oxygen tension and consumption; bile secretion; bile acids; cholesterol; lipids; tissue blood flow; blood supply; portal pressure.
\end{abstract}

\section{INTRODUCTION}

One of the gaseous signalling molecule, hydrogen sulfide $\left(\mathrm{H}_{2} \mathrm{~S}\right)$, plays an important role in regulation of body functions. It can easily penetrate cell membranes, interact with intracellular proteins without the involvement of the cell surface receptors, and its formation is regulated by enzymes [1]. In recent years, studies of the effect of $\mathrm{H}_{2} \mathrm{~S}$ on the functioning of various organs and systems of the body have become systematic [2-8]. Endogenous $\mathrm{H}_{2} \mathrm{~S}$ is synthesized from the amino acid L-cysteine, which comes with food or can be formed during protein breakdown or from L-methionine through transsulfurization. There are two main pathways of L-cysteine catabolism. One of them includes oxidation of the SH group catalyzed by cysteine dioxygenase to form cysteine sulfinate, which can then be converted to hypotaurine or pyruvate and sulfite by decarboxylation. The second pathway utilizes the sulfur atom from L-cysteine without its oxidation to form a molecule of hydrogen sulfide. The processes along the second pathway are catalysed by pyridoxal-5'-phosphate-dependent enzymes - cystathionine- $\beta$-synthase (CBS) and cystathionine- $\gamma$-lyase (CSE) - the main source of $\mathrm{H}_{2} \mathrm{~S}$ production in the liver [1,2]. CSE differs from CBS by mechanism of hydrogen sulfide synthesis. The former catalyses the conversion of L-cysteine into thiocysteine, pyruvate and ammonium ion $[8,9]$. The thiocysteine decomposes then non-enzymatically to produce $\mathrm{L}$-cysteine and $\mathrm{H}_{2} \mathrm{~S}$. Another pathway, involving (C) P.I. Yanchuk, I.V. Komarov, Y.A. Levadianska, L.O. Slobodianyk, S.P. Veselsky, T.V. Vovkun, L.Ya. Shtanova, E.M. Reshetnik 
the CBS, consists in the condensation of cysteine with homocysteine, synthesizing cystathionine with the release of hydrogen sulfide. It should be noted that both these enzymes are common in body tissues. However, the vast majority of CBS is located in the central nervous system, and CSE is mainly distributed in cardiovascular system. Both types of enzymes have been found in some organs, such as liver and kidneys. The liver also expresses the enzyme 3-mercaptopyruvate sulfurtransferase (MPST). However, according to the literature, inhibition of MPST expression significantly enhances rather than reduces $\mathrm{H}_{2} \mathrm{~S}$ production, whereas MPST overexpression markedly inhibits $\mathrm{H}_{2} \mathrm{~S}$ synthesis. Experiments on co-immunoprecipitation have shown that MPST directly interacts and negatively regulates CSE [2].

It has been experimentally confirmed that an impaired synthesis of enzymes in the liver causes the development of fibrosis, steatosis, hyperhomocysteinemia and changes in the regulation of genes responsible for the synthesis of lipids in the liver $[9,10]$. CSE is expressed in hepatocytes and stellate cells of the liver [11]. By acting on stellate cells, $\mathrm{H}_{2} \mathrm{~S}$ causes dilation of microvessels in this organ.

Because the liver is one of the most multifunctional and metabolically active organs, most of the synthetic processes in it occur with increased intensity of tissue respiration. In particular, such a specific function of the liver as the formation and secretion of bile directly depends on the oxygen-dependent processes [12-16]. These include the synthesis of bile acids and lipids, which are the main components of bile $[17,18]$, as well as the transport of its individual organic components [19]. Recent studies have shown that $\mathrm{H}_{2} \mathrm{~S}$ has a potent vasodilating effect [7] and can affect liver function [20]. The hydrogen sulfide donor NaHS was shown to cause a decrease in bile synthesis and excretion of bicarbonate, while the opposite effect was observed after CSE blockade [21]. It is believed that the main mechanism by which L-cysteine exerts its influence on liver is its regulatory function as a precursor of hydrogen sulfide [22-24].
There are several studies showing the effect of hydrogen sulfide on liver function [20,21]. However, the effect of $\mathrm{H}_{2} \mathrm{~S}$ on liver tissue respiration, blood supply and bile secretion remains poorly investigated and represents the aim of the present study.

\section{METHODS}

Acute in vivo experiments were performed on 86 white laboratory Wistar rats of both sexes weighing 250-300 g. The animals were anesthetized by intraperitoneal administration of urethane solution $(1 \mathrm{~g} / \mathrm{kg})$. Oxygen tension $\left(\mathrm{pO}_{2}\right)$ in the liver was measured by LP-9 polarograph in chronoamperometric mode at a fixed voltage of 0.6 V, using 2-3 glass-covered platinum (indicator) electrodes located in different parts of the liver. A standard calomel electrode from a $\mathrm{pH}$ meter was used as a reference electrode. Oxygen consumption by the liver was assessed by its oxygen consumption ratio, calculated by the rate of decrease in oxygen tension in the liver parenchyma during half-minute occlusion of the portal vein and hepatic artery [16]. Blood pressure in the carotid artery (BP) and portal vein (PVP) were measured with an electromanometer EMT-31, the changes in the liver blood supply (HBF) - by a rheographic method in our modification [25] using a rheograph RG-4-01. Local blood flow in the liver (LBF) was studied by a method of hydrogen clearance with its electrochemical generation [15], using a pair of platinum electrodes (generating and recording) and a polarograph LP-9. The recording electrode was polarized by a voltage of 250-300 $\mathrm{mV}$. Hydrogen generation took place at the cathode at a current of $5 \mu \mathrm{A}$. The standard calomel electrode served as a reference electrode of the registration circuit. A $1 \mathrm{~cm}^{2}$ silver plate was used as the passive electrode of the generation circuit. All values were measured using the recorder H071.6M.

The compounds were injected into the portal vein at the following doses: the substrate of the $\mathrm{H}_{2} \mathrm{~S}$ biosynthesis, L-cysteine ("Sigma", USA) - $20 \mathrm{mg} / \mathrm{kg} ; \mathrm{H}_{2} \mathrm{~S}$ synthesis inhibitor, DL-pro- 
pargylglycine ("Sigma”, USA) - $11 \mathrm{mg} / \mathrm{kg}$. Rats of the control group were injected with saline at a dose of $1 \mathrm{ml} / \mathrm{kg}$ body weight.

Bile collection was performed from the cannulated bile duct. During the first $30 \mathrm{~min}$, the initial level of bile secretion was determined by collecting three 10-minute portions of bile. The mean volumetric rate of bile secretion was calculated in microliters per minute per $1 \mathrm{~g}$ of liver $(\mu \mathrm{l} / \mathrm{min} \cdot \mathrm{g})$. After sampling of bile batch No. 1 for the first 30 min of experiment (basal level), the rats were administered intraportally the following substances: saline at the dose of $1 \mathrm{ml} / \mathrm{kg}$ body weight (control), L-cysteine ("Sigma", USA) - 20 mg/kg, DL-propargylglycine ("Sigma", USA) - $11 \mathrm{mg} / \mathrm{kg}$ and after $30 \mathrm{~min}$ - L-cysteine in the specified dose. The duration of the acute experiment was $3 \mathrm{~h}$, so in each series of experiments we collected totally 6 bile samples every $30 \mathrm{~min}$. Separation of bile acid fractions in the collected bile samples was performed by thin layer chromatography. To separate the bile acid phase, a mixture of ethanol and acetone $(3: 1)$ was added to the bile, which extracted mixture of ethanol and acetone was centrifuged after keeping in the freezer for 25-30 min. The dry residue was dissolved in a mixture of ethanol-water $(6: 4)$.

A mixture of amylacetate-toluene-butanolacetic acid-water (3: 1: 1: 3: 1) was used as the solvent for the chromatographic separation. Quantitative determination of bile acids and cholesterol was performed using a K-1 densitometer $(\lambda=620 \mathrm{~nm})$ after staining the plates, according to the calibration curves as described [25]. The method used made it possible to determine the following bile acids in the bile: taurocholic, taurohenodeoxycholic and taurodeoxycholic (mixture), glycocholic, glycochenodeoxycholic and glycodeoxycholic (mixture), cholic, chenodeoxycholic and desoxycholic (mixture). The concentration of bile acids was calculated in $\mathrm{mg} \%$.

During the experiment, intrarectal temperature of rats was recorded using an electrothermometer TPEM- 1 and maintained at $38 \pm 0,5^{\circ} \mathrm{C}$ using an electric animal heater.
All conducted experimental studies comply with the principles of the European Convention for the protection of vertebrate animals used for research and other scientific purposes (Strasbourg, 1986), EEC Directive No. 609 (1986) and the order of the Ministry of Health of Ukraine No. 281 from 01.11.2000 "On measures to further improvement of organizational standards for the use of experimental animals."

Statistical analysis was performed using the Statistica 7.0 software ("Stat Soft", USA). The normality test was performed using the ShapiroWilk test. In the case of normal distribution (this applies to changes in blood circulation and oxygen homeostasis in the liver), the statistical results were presented in $(\mathrm{M} \pm \mathrm{SD})$. The results of studies of biliary secretory function of the liver had a distribution different from normal. Differences between the animal groups were estimated by Mann-Whitney test, and between the baseline and samples No. 2-6 - by Wilcoxon test. Differences at $\mathrm{P}<0.05$ were considered significant.

\section{RESULTS AND DISCUSSION}

The effect of endogenous hydrogen sulfide on liver function was studied using its precursor L-cysteine. The level of oxygen tension in the liver parenchyma of experimental rats was $46.2 \pm 2.3 \mathrm{~mm} \mathrm{Hg}$. Intraportal administration of L-cysteine at a dose of $20 \mathrm{mg} / \mathrm{kg}$ caused a significant decrease in $\mathrm{pO}_{2}$ in the liver with a maximum drop by $37.1 \%(\mathrm{P}<0,01)$ compared to the initial levels at 65 th min of the experiment (Table 1). These results may indicate the activation of processes associated with the intensification of oxygen consumption by the liver, which led to a decrease in $\mathrm{pO}_{2}$ level. Indeed, as our subsequent results have shown, administration of L-cysteine to rats caused a significant increase in the intensity of tissue respiration in the liver. The oxygen consumption coefficient of the liver $(\mathrm{K})$ increased by $38.6 \%$ $(\mathrm{P}<0,01)$ at the maximum of the response $(60 \mathrm{th}$ min after the administration of L-cysteine). 
As mentioned above, endogenous hydrogen sulfide synthesis occurs from the amino acid L-cysteine mainly with the participation of the enzyme cystathionine- $\gamma$-lyase. The CSE mRNA was found in hepatocytes, vascular endothelium and stellate cells of the liver [26]. The direct effect of L-cysteine on the vessels of the liver, without its conversion to hydrogen sulfide [5] also cannot be excluded. The same applies to the hepatocyte function. Therefore, we decided to investigate the effect of this amino acid on liver oxygen homeostasis under the action of the selective inhibitor of cystathionine- $\gamma$-lyase DL-propargylglycine.

The administration of DL-propargylglycine in the presence of L-cysteine eliminated the changes in $\mathrm{pO}_{2}$ in the liver and significantly inhibited the tissue respiration. Thus, the level of oxygen tension in the liver under the blockade of $\mathrm{H}_{2} \mathrm{~S}$ synthesis varied in response to L-cysteine insignificantly. The oxygen consumption coefficient, which in response to the action of L-cysteine before the administration of DL-propargylglycine was increased by $38.6 \%$, increased by $12.2 \%$ only $(\mathrm{P}<0.05)$ upon the blockade of hydrogen sulfide synthesis. These results may indicate that the effect of L-cysteine on liver tissue respiration is mediated mainly by hydrogen sulfide synthesized from this amino acid.

However, a decrease in the level of $\mathrm{pO}_{2}$ in the liver may be associated with both an increase in tissue respiration and a decrease in the oxygen supply. Therefore, we decided to test the effect of $\mathrm{H}_{2} \mathrm{~S}$ on hepatic blood circulation. Upon administration of L-cysteine, the PB and PVP decreased by 17.6 and $24.5 \%(\mathrm{P}<0.001)$, respectively, HBF and LBF increased by 28.2 and $24.4 \%$ ( $\mathrm{P}<0.001)$, respectively (Table 1$)$. Our results indicate that the precursor of endogenous synthesis of $\mathrm{H}_{2} \mathrm{~S}$ L-cysteine causes a dilation of blood vessels of the liver, reduces blood pressure and increases the rate of tissue blood flow in the liver and blood supply.

The response of the studied parameters induced by L-cysteine after the prior administration of DL-propargylglycine were not only eliminated, but could be changed to the opposite. Thus, the BP and PVP, which decreased before the blockade of $\mathrm{H}_{2} \mathrm{~S}$ synthesis, now increased by $20.4 \%(\mathrm{P}<0.05)$ and $26.6 \%(\mathrm{P}<0.01)$, respectively. The $\mathrm{HBF}$ and $\mathrm{LBF}$ in the liver, which before the blockade were increased, after the blockade were decreased by 21.5 and $11.7 \%(\mathrm{P}<0,01)$, respectively, compared with the initial values of these parameters (Table 1). Such response of the hepatic vascular system

Table 1. Changes in oxygen tension $\left(\mathrm{pO}_{2}\right)$ in the liver parenchyma, its oxygen consumption coefficient $(\mathrm{K})$, systemic blood pressure (BP), portal vein pressure (PVP), hepatic blood flow (HBF) and its local blood flow (LBF) in rats upon intra-portal administration of L-cysteine $(20 \mathrm{mg} / \mathrm{kg})$ before and against the background of DL-propargylglycine at a dose of $11 \mathrm{mg} / \mathrm{kg}(\mathrm{M} \pm \mathrm{SD}, \mathrm{n}=38)$

\begin{tabular}{|l|c|c|c|c|c|c|}
\hline \multirow{2}{*}{ Values } & \multicolumn{3}{|c|}{ L-cysteine } & \multicolumn{2}{c|}{$\begin{array}{c}\text { L-cysteine upon the administration of } \\
\text { DL-propargylglycine }\end{array}$} \\
\cline { 2 - 7 } & $\begin{array}{c}\text { Initial } \\
\text { level }\end{array}$ & $\begin{array}{c}\text { Maximum } \\
\text { response }\end{array}$ & $\begin{array}{c}\text { Percent from } \\
\text { the initial } \\
\text { level }\end{array}$ & Initial level & $\begin{array}{c}\text { Maximum } \\
\text { response } \\
\text { from the } \\
\text { initial } \\
\text { level }\end{array}$ \\
\hline $\mathrm{pO}_{2}, \mathrm{~mm} \mathrm{Hg}$ & $46.2 \pm 2.3$ & $29.1 \pm 1.8^{* *}$ & 62.9 & $48.5 \pm 2.6$ & $45.7 \pm 2.5$ & 94.2 \\
$\mathrm{~K} \cdot 10^{-2}, \mathrm{au}$ & $2.12 \pm 0.11$ & $2.94 \pm 0.14^{* *}$ & 138.6 & $2.05 \pm 0.11$ & $2.30 \pm 0.12^{*}$ & 112.2 \\
$\mathrm{BP}, \mathrm{mm} \mathrm{Hg}$ & $85.7 \pm 7.3$ & $70.7 \pm 9.7^{* * *}$ & 82.4 & $90.9 \pm 7.3$ & $107.0 \pm 10.4 * * *$ & 117.7 \\
$\mathrm{PVP}, \mathrm{mm} \mathrm{Hg}$ & $9.0 \pm 3.1$ & $6.8 \pm 2.4^{* *}$ & 75.5 & $7.2 \pm 1.7$ & $9.6 \pm 1.4^{* * *}$ & 133.3 \\
$\mathrm{HBF}, \mathrm{ml} / 100 \mathrm{~g}$ & $20.5 \pm 2.2$ & $26.3 \pm 1.7^{* * *}$ & 128.2 & $19.6 \pm 4.2$ & $16.8 \pm 2.1 * *$ & 85.7 \\
$\mathrm{LBF}, \mathrm{ml} / \mathrm{min} \cdot 100 \mathrm{~g}$ & $93.4 \pm 7.3$ & $116.2 \pm 11.9 * * *$ & 124.4 & $102.7 \pm 17.7$ & $87.0 \pm 11.9 * * *$ & 84.7 \\
\hline $\mathrm{N}$
\end{tabular}

Notice: $* \mathrm{P}<0.05, * * \mathrm{P}<0.01, * * * \mathrm{P}<0.001$, compared to the initial level 
indicated that DL-propargylglycine blocked the action of the enzyme CSE, thereby inhibiting both the $\mathrm{H}_{2} \mathrm{~S}$ synthesis from exogenous L-cysteine and its endogenous synthesis from the precursors in the blood. As a result, the intrahepatic vessels constricted, which led to an increase in the blood pressure and a decrease in the rate of tissue blood flow in the liver and the volume of blood deposited in it. Some differences in the responses of hepatocytes and hepatic blood vessels to L-cysteine upon the DL-propargylglycine administration may be explained by their different sensitivity to the same concentration of endogenous $\mathrm{H}_{2} \mathrm{~S}$.

$\mathrm{H}_{2} \mathrm{~S}$ can exert its vasodilatory effect on the portal vessels of the liver by activating ATP-sensitive potassium channels ( $\mathrm{K}_{\text {ATP }}$ channels) [5]. The main result of the action of this molecule is hyperpolarization, a phenomenon that is not associated with the activation of guanylate cyclase [27]. $\mathrm{H}_{2} \mathrm{~S}$, by affecting the $\mathrm{K}_{\text {ATP }}$ channels that are sensitive to the concentration of adenosine triphosphate (ATP), causes membrane hyperpolarization in the smooth muscle cells [28]. The binding of $\mathrm{H}_{2} \mathrm{~S}$ to the channels causes changes in their spatial configuration, which leads to increased release of potassium ions from the cell into the intercellular space. Recent studies have shown that $\mathrm{Ca}^{2+}$-dependent potassium channels ( $\mathrm{K}_{\mathrm{Ca}}$ channels) were also activated by $\mathrm{H}_{2} \mathrm{~S}$ [29]. $\mathrm{H}_{2} \mathrm{~S}$ increased the activity of $\mathrm{Ca}^{2+}$ sparks in the smooth muscles, which is necessary for the activation of endothelial $\mathrm{Ca}^{2+}$-dependent potassium channels of high conductance $\left(\mathrm{BK}_{\mathrm{Ca}}\right.$-channels) [30]. At the same time, the activation of $K_{\text {ATP }}$ channels was accompanied by the suppression of voltage-dependent L-type calcium channels, which ensured the $\mathrm{Ca}^{2+}$ entry into the cell. High intracellular $\mathrm{Ca}^{2+}$ concentration is a prerequisite for the smooth muscle contraction. Closure of these channels caused a decrease in the concentration of free intracellular $\mathrm{Ca}^{2+}$ [7]. Therefore, inhibition of voltage-dependent calcium channels caused a decrease in intracellular $\mathrm{Ca}^{2+}$ concentration and vascular relaxation.

Our data on the dilating effect of L-cysteine on the liver vessels and the blockade of it effects by propargylglycine are consistent with the results of the study carried out by other authors on aortic fragments [31]. These results also confirm the data on the activation of liver tissue respiration under the effect of L-cysteine obtained earlier by other researchers [32].

Thus, the recorded decrease in the $\mathrm{pO}_{2}$ levels, observed despite the increase in the supply of oxygen to the functional elements of the liver under the action of L-cysteine, can be explained by the increase in the intensity of the liver tissue respiration. Therefore, we next decided to test the possibility of the effect of L-cysteine on the volumetric rate of bile secretion and oxygen-dependent processes of formation of its components.

Under saline administration, the rate of bile secretion in the control rats ranged from $1.18 \pm$ 0.36 to $1.32 \pm 0.38 \mu \mathrm{l} / \mathrm{min} \cdot \mathrm{g}$ of liver. No significant changes in initial bile flow were observed in all half-hour bile samples during the experiment, although there was a clear tendency for decreased bile secretion. This can be explained by an impairment of the enterohepatic circulation of bile acids. At the same time, we observed a decrease in the concentrations of tauroconjugates in the bile (Table 2). Their maximum concentrations were observed in the last half-hour samples of bile, namely: the content of taurocholic acid decreased by $9.8 \%(\mathrm{P}<0.05)$ compared to the initial level, and the concentration of a mixture of taurodeoxycholic and taurohenodeoxycholic acids decreased by $16.1 \%(\mathrm{P}<0.05)$ relative to the initial value.

We have also observed a decrease in the concentration of phospholipids in the bile of these animals by $10.9 \%(\mathrm{P}<0.05)$, compared to the initial values, as well as in cholesterol, free fatty acids and cholesterol esters concentrations. However, these changed were not statistically significant (Table 3 ). A decrease in the concentration of bile acids and phospholipids in the hepatic secretion of control rats during the experiment most likely results from the interruption of enterohepatic circulation and a 
decrease in the blood supply to the liver.

Because the control and experimental groups of animals were formed separately, these changes may affect the variability of the initial values of the studied parameters in different animals. Therefore, it was more appropriate in this case to compare the changes in the measured parameters after the introduction of the test substance with their initial levels in the same group of animals. This comparison was done in the next step of the study.

Intraportal administration of L-cysteine had a hypocholeretic effect, which was registered immediately after the administration of the amino acid into the portal vein with the most significant decrease in the volume of the secreted bile by $18.9 \%(\mathrm{P}<0.01)$ in the 6 th half-hour sample compared to the initial value.

The changes in the dynamics of bile secre- tion detected under the influence of L-cysteine may be associated with changes in intracellular metabolic processes in hepatocytes, which are involved in the bile formation. It can be assumed that this applies to the processes of active extraction of bile acids from sinusoidal blood, their biotransformation, conjugation with taurine and glycine, hydroxylation, and intracellular transport or active transfer across the canalicular membrane with changes in their concentration in the primary bile ducts, as these processes form the basis of bile formation [12].

Under the action of L-cysteine, the content of tauroconjugates increased relative to the initial values in the bile of rats, in particular, the concentration of taurocholic acid increased by $10.3 \%(\mathrm{P}<0.05)$ maximum in the 4 th halfhour sample and a mixture of taurodeoxycholic

Table 2. Dynamics of changes of bile acids concentrations $(\mathbf{m g} \%)$ in bile of rats upon intraportal administration of Lcysteine at a dose of $20 \mathrm{mg} / \mathrm{kg}(\mathrm{n}=14), \mathrm{Me}[25 \% ; 75 \%]$

\begin{tabular}{|c|c|c|}
\hline \multirow{2}{*}{$\begin{array}{l}\text { No. of the } \\
\text { samples }\end{array}$} & \multicolumn{2}{|c|}{ Fractions of the bile acids } \\
\hline & Taurocholic acid & $\begin{array}{c}\text { Taurodeoxycholic and tauro- } \\
\text { chenodeoxycholic acid }\end{array}$ \\
\hline \multicolumn{3}{|c|}{ Control } \\
\hline 1 & $176.6[171.2 ; 190.9]$ & $105.5[102.8 ; 108.2]$ \\
\hline 2 & $174.9[170.3 ; 189.3]$ & $106.9[101.9 ; 111.6]$ \\
\hline 3 & $172.1[168.6 ; 187.5] \#$ & $103.3[95.0 ; 105.5]$ \\
\hline 4 & $172.7[164.0 ; 185.7] \#$ & $98.0[93.7 ; 101.9] \#$ \\
\hline 5 & $166.3[161.3 ; 177.6] \#$ & $93.4[92.0 ; 99.0] \#$ \\
\hline 6 & $159.3[151.4 ; 172.1] \#$ & $88.5[86.7 ; 92.0] \#$ \\
\hline \multicolumn{3}{|c|}{ L-cystein administered rats } \\
\hline 1 & $173.0[147.9 ; 181.1]$ & $81.2[66.9 ; 92.0]^{* *}$ \\
\hline 2 & $178.5[163.9 ; 191.0] \#$ & $92.0[74.0 ; 95.7]^{* \#}$ \\
\hline 3 & $185.0[171.2 ; 198.3] \#$ & $95.7[77.7 ; 108.2] \#$ \\
\hline 4 & $190.8[169.5 ; 204.5] \#$ & $88.5[74.0 ; 110.9] \#$ \\
\hline 5 & $181.1[164.0 ; 198.5] \#$ & $81.2[69.6 ; 107.3] \#$ \\
\hline 6 & $177.6[161.3 ; 191.0] \#$ & $72.2[65.0 ; 103.7]$ \\
\hline \multicolumn{3}{|c|}{ DL-propargylglycine + L-cysteine administered rats } \\
\hline 1 & $179.6[147.9 ; 181,1]$ & $83.4[66.9 ; 92.0]$ \\
\hline 2 & $183.9[163.9 ; 189.0]$ & $83.7[74.0 ; 95.7]$ \\
\hline 3 & $187.9[171.2 ; 192,3] \#$ & $89.1[77.7 ; 98.2] \#$ \\
\hline 4 & $186.5[169.5 ; 189.5] \#$ & $89.6[74.0 ; 97.9] \#$ \\
\hline 5 & $177.2[164.0 ; 188.5]$ & $85.6[69.6 ; 96.3]$ \\
\hline 6 & $174.2[161.3 ; 191.0]$ & $87.8[65.0 ; 103.7]$ \\
\hline
\end{tabular}

Notice: ${ }^{*} \mathrm{P}<0.05$ relative to the initial level; $\# \mathrm{P}<0.05$ relative to the initial level (concentration of bile acids in a half-hour bile sample obtained before the administration of the test compound(s)) 
and taurohenodeoxycholic acids concentrations increased in the 3rd sample by $17.9 \%$ $(\mathrm{P}<0.05)$ compared to the initial values (Table 2$)$. At the same time, there was a decrease in the 6th half-hour sample of phospholipids by $21.5 \%$ $(\mathrm{P}<0.05)$ in the bile of the same animals, cholesterol by $33.9 \%(\mathrm{P}<0.01)$ and free fatty acids by $15.8 \%(\mathrm{P}<0.05)$ (Table 3$)$. The level of cholesterol esters increased by $22.6 \%(\mathrm{P}<0.01)$ compared to the initial levels.

The results obtained suggest that due to the intensification of biosynthesis and conjugation of bile acids, there was a significant reduction in free cholesterol concentration. In addition, the processes of its esterification were intensified, as indicated by the increase in the concentration of esterified cholesterol in the bile of rats. The latter was confirmed by a decrease in the level of free bile acids concentrations. The free acids are involved in the biosynthesis of cholesterol esters and intensification of tissue respiration in the liver, and can be used as substrates for oxidation.

Primary free bile acids (cholic and chenodeoxycholic) are synthesized in the liver of most animals from cholesterol in different ways. In particular, the biosynthesis of cholic acid occurs through the so-called "neutral pathway" with the participation of microsomal oxidation enzymes directly in the cytoplasm of hepatocytes. Along with this, the synthesis of chenodeoxycholic acid in the so-called "acidic pathway" proceeds in the mitochondria with the participation of mitochondrial enzymes. Free deoxycholic and sometimes lithocholic acids present in bile are products of dehydroxylation of cholic and de-

Table 3. Dynamics of changes of separate fractions of lipids (mg\%) in bile of rats at intraportal administration of L-cysteine at a dose of $20 \mathrm{mg} / \mathrm{kg}(\mathrm{n}=14), \mathrm{Me}[25 \% ; 75 \%]$

\begin{tabular}{|c|c|c|c|c|}
\hline \multirow{2}{*}{$\begin{array}{l}\text { No. of the } \\
\text { samples }\end{array}$} & \multicolumn{4}{|c|}{ Lipid fractions in the bile of rats } \\
\hline & Phospholipids & Cholesterol & Free fatty acids & Cholesterol esters \\
\hline \multicolumn{5}{|c|}{ Control } \\
\hline 1 & $68.7[64.1 ; 70.1]$ & $22.3[21.7 ; 22.8]$ & $12.7[11.6 ; 12.8]$ & $2.8[2.6 ; 3.3]$ \\
\hline 2 & $67.8[64.8 ; 72.2]$ & $23.1[22.8 ; 23.6]$ & $12.8[11.9 ; 13.3]$ & $2.8[2.5 ; 3.2]$ \\
\hline 3 & $65.0[65.0 ; 69.6]$ & $22.5[22.3 ; 23.4]$ & $12.0[11.9 ; 14.1]$ & $2.7[2.6 ; 3.3]$ \\
\hline 4 & $65.9[64.1 ; 66.7]$ & $22.1[22.1 ; 22.8]$ & $12.8[12.6 ; 12.9]$ & $2.7[2.7 ; 34]$ \\
\hline 5 & $63.2[63.2 ; 63.2]^{\#}$ & $21.9[21.3 ; 22.7]$ & $12.4[11.0 ; 12.9]$ & $2.6[2.4 ; 3.1]$ \\
\hline 6 & $61.2[60.5 ; 62.3]^{\#}$ & $21.6[21.5 ; 22.9]$ & $12.3[10.8 ; 12.7]$ & $2.6[2.2 ; 2.9]$ \\
\hline \multicolumn{5}{|c|}{ L-cystein administered rats } \\
\hline 1 & $72.2[67.8 ; 73.1]$ & $24.5[24.1 ; 25.2]$ & $14.6[14.6 ; 15.5]$ & $3.1[2.8 ; 3.3]$ \\
\hline 2 & $72.2[68.7 ; 77.7]$ & $26.2[25.3 ; 26.8]$ & $15.5[13.7 ; 15.5]$ & $3.4[2.9 ; 4.1]$ \\
\hline 3 & $71.3[70.2 ; 74.0]$ & $24.2[24.0 ; 25.1]$ & $14.6[14.2 ; 15.1]$ & $3.2[3.0 ; 3.9]$ \\
\hline 4 & $65.0[65.0 ; 71.3]$ & $22.2[21.9 ; 22.6]^{\#}$ & $13.7[13.3 ; 13.7]$ & $3.4[3.1 ; 3.8]^{\#}$ \\
\hline 5 & $60.9[60.1 ; 69.6]$ & $20.6[20.2 ; 21.3]^{\#}$ & $12.4[11.1 ; 12.8]^{\#}$ & $3.6[3.2 ; 3.9]^{\#}$ \\
\hline 6 & $56.7[55.4 ; 58.9]^{\#}$ & $16.2[19.1 ; 20.2]^{\# \#}$ & $12.3[11.9 ; 12.4]^{\#}$ & $3.8[3.7 ; 4.1]^{\# \#}$ \\
\hline \multicolumn{5}{|c|}{ DL-propargylglycine + L-cysteine administered rats } \\
\hline 1 & $73.6[68.2 ; 75.4]$ & $23.3[22.9 ; 23.8]$ & $15.6[13.9 ; 15.8]$ & $3.2[3.1 ; 3,6]$ \\
\hline 2 & $73.9[70.8 ; 81.1]$ & $22.7[22.3 ; 23.6]$ & $14.4[14.1 ; 15.2]$ & $3.4[2.9 ; 4,1]$ \\
\hline 3 & $69.0[68.4 ; 73.2]$ & $21.4[21.2 ; 22.6]^{\#}$ & $17.1[15.3 ; 17.7]^{\# *}$ & $3.4[3.1 ; 3,9]$ \\
\hline 4 & $65.7[64.8 ; 72.1]^{\#}$ & $19.5[19.3 ; 21.1]^{\#}$ & $16.3[14.2 ; 16.9]$ & $3.4[3.3 ; 3,8]^{\#}$ \\
\hline 5 & $62.7[57.9 ; 68.3]^{\#}$ & $17.7[17.3 ; 19.1]^{\#}$ & $14.3[13.8 ; 15.0]$ & $3.6[3.6 ; 4,1]^{\#}$ \\
\hline 6 & $58.7[54.6 ; 61.5]^{\#}$ & $16.0[15.8 ; 17.4]^{\# \#}$ & $13.4[13.6 ; 14.7]^{\#}$ & $3.9[3.8 ; 4,7]^{\#}$ \\
\hline
\end{tabular}

Notice: ${ }^{*} \mathrm{P}<0.05$ relative to control; ${ }^{\#} \mathrm{P}<0.05$ relative to the initial levels (lipid concentration in the half-hour bile sample obtained before administration of the test compound(s)). 
oxycholic acids catalysed by enzymes of intestinal microorganisms. The formation of bile acids conjugated with glycine and taurine also occurs in hepatocytes from both synthesized in them acids and from those that return to the liver from the enterohepatic cycle. At first glance, the most oxygen-dependent is the biosynthesis of chenodeoxycholic acid, because it is associated with the direct involvement of mitochondria. However, the hydroxylation of cholesterol with the formation of cholic acid is carried out with the involvement of oxygen, and the conjugation of bile acids with glycine or taurine requires activation of the corresponding enzymes with the participation of adenosine triphosphate (ATP). The latter is partially formed during glycolysis, but most of it is produced in the mitochondria of hepatocytes. Thus, most parts of the bile acid metabolism are related to the efficiency of energy metabolism and depend on the ability of liver cells to consume oxygen $[13,14]$.

Our results on the dynamics of changes in the concentration of bile acids under the action of L-cysteine indicated a significant activation of acidic pathway of their biosynthesis, as confirmed by an increase in the taurohenoand taurodeoxycholic acids concentrations by $17.3 \%$ in the bile of rats. In addition, it should be noted that this effect developed much faster than the increase in the level of taurocholic acid in the bile of rats, the synthesis of which occurs with the participation of microsomal oxidation enzymes.

The use of the $\mathrm{H}_{2} \mathrm{~S}$ synthesis blocker DLpropargylglycine reduced the efficiency of bile acid biosynthesis induced by L-cysteine, both with the participation of mitochondrial and microsomal enzymes, which indicated a significant involvement of hydrogen sulfide in this process. However, $\mathrm{H}_{2} \mathrm{~S}$ blockade had almost no effect on the response of bile flow rate and individual lipid fractions in rat bile. That is, these changes are the result of direct action of L-cysteine on hepatocytes and occur without the participation of $\mathrm{H}_{2} \mathrm{~S}$.

\section{CONCLUSIONS}

1. Intra-portal administration of L-cysteine (20 mg/kg), a precursor of hydrogen sulfide synthesis, causes activation of tissue respiration in hepatocytes, and reduction of the level of oxygen tension in rat liver.

2. The increase in oxygen consumption by the liver under the influence of L-cysteine is due to increased oxygen-dependent synthetic processes, in particular, those associated with mitochondrial polyenzyme systems of bile acid biosynthesis through the acidic pathway, oxidation of individual fractions of free fatty acids, as evidenced by a decrease in their content in bile.

3. L-cysteine causes an increase in the concentration of taurocholic acid and a mixture of taurodeoxycholic and taurohenodeoxycholic acids, which reduces the lithogenicity of bile, stabilizing its colloidal state, because the conjugated bile acids are more soluble than corresponding free acids.

4. L-cysteine is actively involved in the regulation of blood circulation in the liver, as evidenced by the dilation of intrahepatic vessels due to its introduction. As a result, blood pressure in the vessels decreases, and the rate of tissue blood flow in the organ and its blood supply increases.

5. Blockade of cystathionine- $\gamma$-lyase by DL-propargylglycine $(11 \mathrm{mg} / \mathrm{kg})$ significantly inhibits tissue respiration and bile acid biosynthesis in the liver under the influence of L-cysteine, and not only completely eliminates the effects of the latter in the vascular bed, but also inhibits the $\mathrm{H}_{2} \mathrm{~S}$ synthesis from its endogenous precursors. This leads to vasoconstriction in the liver and, consequently, to increased blood pressure in it and reduced rate of tissue blood flow and the volume of blood deposited in the liver. These facts indicate a significant involvement of hydrogen sulfide in the above processes.

The authors of this study confirm that the research and publication of the results were not associated with any conflicts regarding commercial or financial 
relations, relations with organizations and/or individuals who may have been related to the study, and interrelations of co-authors of the article.

\section{П.І. Янчук, І.В. Комаров, Ю.А. Левадянська, Л.О. Слободяник, С.П. Весельський, Т.В. Вовкун, Л.Я. Штанова, С.М. Решетнік \\ РОЛЬ СІРКОВОДНЮ У РЕГУЛЯЦІї ТКАНИННОГО ДИХАННЯ, КРОВОПОСТА- ЧАННЯ ТА ЖОВЧОСЕКРЕТОРНОЇ ФУНК- ЦІї ПЕЧІНКИ}

Київський національний університет

імені Тараса Шевченка; e-mail: yanchuk49@ukr.net

В гострих експериментах внутрішньопортальне введення лабораторним щурам попередника синтезу сірководню L-цистеїну (20 мг/кг) стимулює споживання кисню печінкою на $38,6 \%$, рівень напруження кисню в ній при цьому знижується на 37,1\%. Активація тканинного дихання відбувається завдяки посиленню киснезалежних синтетичних процесів у залозі, зокрема, пов'язаного 3 мітохондріальними поліферментними системами біосинтезу жовчних кислот «кислим шляхом»: концентрації таурохолевої кислоти та суміші тауродезоксихолевої і таурохенодезоксихолевої кислот зростають на 10,3 та на $17,9 \%$ відповідно порівняно з вихідним рівнем. Водночас суттєво знижується вміст вільного холестерину на $33,9 \%$ та посилюються процеси його етерифікації, на що вказує зростання в жовчі щурів концентрації етерифікованого холестерину на 22,6\%. Останнє певною мірою підтверджується зниженням вмісту вільних жовчних кислот на $15,8 \%$, які включаються в біосинтез ефірів холестерину та інтенсифікації процесів тканинного дихання в печінці, і можуть використовуватись як субстрат для окиснення. Дія L-цистеїну спричинює розширення внутрішньопечінкових судин, внаслідок чого системний артеріальний тиск і тиск крові у ворітній вені вірогідно знижуються на 17,6 і 24,5\% відповідно, а швидкість локального кровотоку в печінці та їі кровонаповнення збільшуються на 28,2 і $24,4 \%$ відповідно. Блокада цистатіонін- $\gamma$-ліази за допомогою DL-пропаргілгліцину (11 мг/кг) значно пригнічує тканинне дихання в печінці та біосинтез жовчних кислот під впливом L-цистеїну, а також не тільки повністю усуває ефекти останнього в судинному руслі, але й зумовлює пригнічення синтезу $\mathrm{H}_{2} \mathrm{~S}$ з ендогенних його попередників, а це призводить до звуження кровоносних судин печінки i, як наслідок, до підвищення тиску крові в них та зменшення швидкості тканинного кровотоку і об'єму депонованої в органі крові, що свідчить про істотне залучення до цього процесу сірководню.

Ключові слова: сірководень; L-цистеїн; печінка; напруження кисню та його споживання; секреція жовчі; жовчні кислоти; холестерин; ліпіди; тканинний кровотік; кровонаповнення; портальний тиск.

\section{REFERENCES}

1. Wang R. Physiological implication of hydrogen sulfide: a whiff exploration that blossomed. Physiol Rev. 2012; 92(2):791-896.

2. Li M, Xu C, Shi J, Ding J, et al. Fatty acids promote fatty liver disease via the dysregulation of 3-mercaptopyruvatesulfurtransferase/hydrogen sulfide pathway. Gut. 2018 Dec;67(12):2169-80.

3. Donnarumma E, Trivedi RK, and Lefer DJ. Protective actions of $\mathrm{H}_{2} \mathrm{~S}$ in acute myocardial infarction and heart failure. Compr Physiol. 2017;7(2): 583-602.

4. Wang J, Wang W, Li S, Han Y, Zhang P, Meng G, et al. Hydrogen sulfide as a potential target in preventing spermatogenic failure and testicular dysfunction. Antioxid Redox Signal. 2018; 28(16):1447-62.

5. Semenykhina OM, Bazilyuk OV, Korkach YP, Sagach VF. Mechanisms of hydrogen sulfide effects on contractile activity of vascular smooth muscle in rats. Fiziol. Zh. 2011;57(4):3-12. [Ukrainian].

6. Mys LA, Strutynska NA, Goshovska YV, Sagach VF. Stimulation of the endogenous hydrogen sulfide synthesis suppresses oxidative-nitrosative stress and restores endothelial-dependent vasorelaxation in old rats. Can J Physiol Pharmacol. 2020;98(5):275-81.

7. Xiao Yu Tiana, Wing Tak Wonga, et al. NaHS relaxes rat cerebral artery in vitro via inhibition of 1-type voltagesensitive $\mathrm{Ca}^{2+}$ channel. Pharmacol Res. 2012; 65:239-46.

8. Adrienne L, King AL, Lefer DJ. Cytoprotective actions of hydrogen sulfide in ischaemia-reperfusion injury. Exp. Physiol. 2011;96(9):840-6.

9. Renga B. Hydrogen sulfide generation in mammals: the molecular biology of cystathionine-beta-synthase (CBS) and cystathionine-gamma-lyase (CSE). Inflamm. Allergy Drug Targets. 2011;10:85-91.

10. Robert K, Nehme J, Bourdon E, et al. Cystathionine beta synthase deficiency promotes oxidative stress, fibrosis, and steatosis in mice liver. Gastroenterology. 2005; 128:1405-15.

11. Fiorucci S, Distrutti E, Cirino G, Wallace JL. The emerging roles of hydrogen sulfide in the gastrointestinal tract and liver. Gastroenterology. 2006;131:259-71.

12. Esteller A. Physiology of bile secretion. World J Gastroenterol. 2008;14, (37): 5641-9.

13. Pellicoro A. Human and rat bile acid-CoA: amino acid Nacyltransferase are liver-specific peroxisomal enzymes: implications for intracellular bile salt transport. Hepatology. 2007;45(2):340-8.

14. Hofmann AF. Bile acids: chemistry, pathochemistry, biology, pathobiology, and therapeutics. Cell Mol Life Sci. 2008;65(16):2461-83.

15. Yanchuk PI, Bondzyk OV, Reshetnik YeM, Veselsky SP. Effect of L-arginine on oxygen balance of the liver and the bile secretion function. Fiziol Zh. 2013;59(2):31-8. [Ukrainian].

16. Yanchuk PI, Athamnah SM, Reshetnik YM, et al. Contribution of serotonin to regulation of tissue respira- 
tion and bile secretory function of the liver. Fiziol $\mathrm{Zh}$. 2015;61(2):103-11. [Ukrainian].

17. Lefebvre P, Cariou B, Lien F. Role of bile acids and bile acid receptors in metabolic regulation. Physiol Rev. 2009;89(1),147-91.

18. Dikkers, A. Biliarycholesterol secretion: more than a simple ABC. World J Gastroenterol. 2010;16(47), 5936-45.

19. Li Y, Wang X, Shen Z. Traditional Chinese medicine for lipid metabolism disorders. Am J Transl Res. 2017;9(5), 2038-49.

20. Sarathi Mania, Wei C, et al. Hydrogen sulfide and the liver. Nitric Oxide. 2014;10:1006-16.

21. Fujii K, Sakuragawa T, Kashiba M, et al. Hydrogen sulfide as an endogenous modulator of biliary bicarbonate excretion in the rat liver. Antioxid Redox Signal. 2005;7:788-94.

22. Haouzi P, Sonobe T. Cardiogenics hock induced reduction in cellular $\mathrm{O}_{2}$ delivery as a hall markofacute $\mathrm{H}_{2} \mathrm{~S}$ intoxication. Clin Toxicol (Philadelphia, Pa). 2015; 53(4), 416-7.

23. Abou-Hamdan A, Guedouari-Bounihi H, Lenoir V. Oxidation of $\mathrm{H}_{2} \mathrm{~S}$ in mammalian cells and mitochondria. Methods Enzymol. 2015;554,201-28.

24. Norris EJ, Culberson CR, Narasimhan S. The liver as a central regulator of hydrogen sulfide. Shock. 2011;36 (3), 242-50.

25. Melnichuk DO, Tomchuk VA, Yanchuk PI, et al. Methods of investigation the functional state of the liver and biliary system. Kyiv: NULES of Ukraine. 2015.

26. Fiorucci S, Antonelli E, Distrutti E, et al. Inhibition of hydrogen sulfide generation contributes to gastric injury caused by non-steroidal anti-inflammatory drugs. Gastroenterology. 2005;129:1210-24.

27. Melnyk AB, Voloschuk NO, Pentyuk NO, Zaichko KO. The role of hydrogen sulphide and amino acids sulfurcontaining in regulation tone of vascular smooth muscle wall the rats. Neurophysiology. 2010;42(2):126-31. [Ukrainian].

28. Jang G, Wu L, Liang W, Wang R. Direct stimulation of K(ATP) channels by exogenous and endogenous hydrogen sulfide in vascular smooth muscle cells. Mol Pharmacol. 2005;68:1757-64.

29. Hedegaard ER, Gouliaev A, Winther AK, Arcanjo DD, Aalling M, Renaltan NS, et al. Involvement of potassium channels and calcium-independent mechanisms in hydrogen sulfide-induced relaxation of rat mesenteric small arteries. J Pharmacol Exp Ther. 2016;356(1):53-63.

30. Jackson-Weaver O, Osmond JM, Naik JS, Gonzalez Bosc LV, Walker BR, Kanagy NL. Intermittent hypoxia in rats reduces activation of $\mathrm{Ca}^{2+}$ sparks in mesenteric arteries. Am J Physiol Heart Circ Physiol. 2015; 309(11):H1915-22.

31. Drachuk KO, Kotsiuruba AV, Baziliuk OV, Stepanenko LH, Sahach VF. Propargylglycine restores endotheliumdependent relaxation of aortic smooth muscles in old rats. Fiziol Zh. 2014;60(4):3-10. [Ukrainian].

32. Strutynska NA, Korkach YuP, Mys LA, Luchkova AYu, Sagach VF. L-cysteine stimulates endogenous hydrogen sulfide synthesis, suppresses oxidative stress and mitochondrial permeability transition pore opening in the heart of old rats. Fiziol Zh. 2020;66(2-3):3-12. [Ukrainian].

Received 20.08.2021 